\title{
CHARACTERIZATION AND IDENTIFICATION OF MANGROVE FOREST OF SOUTHERN COAST MALANG REGION IN VIEW OF SUSTAINABILITY CONSERVATION AND MANAGEMENT
}

\author{
Erfan Rohadi $^{1 *}$, Aida Sartimbul ${ }^{2}$ and Imam Fahrurrozi ${ }^{1}$ \\ ${ }^{1}$ The State Polytechnic of Malang, Jl. Soekarno Hatta No. 9, Malang 65141, \\ Indonesia \\ ${ }^{2}$ University of Brawijaya, Faculty of Fisheries and Marine Science, Jl. Veteran \\ No. 16, Malang 65145, Indonesia \\ erfanr@polinema.ac.id
}

\begin{abstract}
The characteristic of Southern of Java coast area is typically rocky beach (rocky shore). Its characteristics which are connected directly to the Indian Ocean may affect the ecosystem of flora and fauna therein. The mangrove performs diverse functions and service on an ecosystem and landscape scale. The important factors for sustainable coastal management are the both economical values and ecological management as the association functions. Furthermore, the typical of tropical marine ecology is a chain as a triangular pattern that means each associated with one another such as the coral reefs, the seagrass and mangrove. Those may have distinct characteristics in the ecosystem. The mangrove in the Southern coast region of Malang grows scattered with various kind of interesting to do data collection based on the characteristics of mangrove found in Southeast Asia. This work presents an attempt to provide helpful information and integrative condition of mangrove ecosystems in Southern coast of Malang Region. The information contains in the form of the identification of species, mangrove biodiversity of the 18 beaches. The proposed methods are on data processing of satellite image ALOS (AVNIR-2) and Landsat 7. The software ENVI 4.4 and Arc GIS 9.3 are used for data processing. The identification of various mangrove species using methods of in situ and laboratory observations. However, the satellite datum must be processed with in situ data so that it provides the informative map with some density classification. The results show that the recent mangrove vegetation (forest) condition in Southern Malang Region is recommended as a prior conservation for sustainability coastal management system. This work also provides the mangrove iBook format and ebook. The hard copy is obliged to the library flora Malang Regency as a supporting information for Southern Malang Region management system and as the academic learning process reference for high school students and universities students.
\end{abstract}

Keywords - Mangrove; Coastal management; Southern Malang; ALOS; Ecosystem; E-book

Received: April 16, 2019

Reviewed: June 23, 2019

Accepted: July 4, 2019

* Corresponding Author 


\section{INTRODUCTION}

Indonesia is an archipelago country that has the largest mangrove forest in the world [1]. Mangrove forests are generally found around the coast of Indonesia and live and grow in locations that have a relationship tidal influence (tidal) seeping in watersheds that are along the coast [2]. The mangrove forest is an ecosystem with an important role in terms of the ecological and socio-economic aspects. The mangrove forest is overgrown with forest type mangrove trees (mangrove) which are typical along the beach or estuary and is influenced by the tide. The mangrove forest has a dual function and is a very important link in maintaining biological balance in a water cycle [3].

As an ecosystem and natural resources, utilization of mangrove directed to the welfare of mankind and to realize its utilization in order to be sustainable. The mangrove ecosystem need to be managed and maintained. Mangrove forest management framework, there are two main concepts. First, the protection of mangrove forest which is a safeguard against mangrove forests into mangrove forest conservation. Second, the rehabilitation of mangrove forests are greening activities performed on land that used to be one of the rehabilitation efforts that aim not only to restore the aesthetic value, but the main thing is to restore the ecological function of mangrove forest that has been logged and transferred its functions to the activity other.

Walters et al., stated that the mangrove forests along the coast and rivers generally provide habitat for many species of fish [4]. Mangrove forests as one of the wetlands in the tropics with easy access and usability of components of biodiversity and high land that has made these resources as tropical endangered resource [5] and became one of the centers of global environmental issues. Increasing conversion of mangrove forests to agricultural land or fish/ shrimp ponds, causing a decrease in productivity of the ecosystem [6]. One of the areas in Malang Region of East Java, which one of still has a fairly extensive mangrove forests is Sinjai area. Management of mangrove forests in this area has been done by the people independently, given some time ago when they sail into various areas, then upon return they bring mangrove seedlings to then planted around the beach because they believe that mangroves have many functions, including can withstand strong winds, large waves, and so on. The increasing tendency of destruction of mangrove forest along with the increasing needs of local communities, such as felling of mangrove trees were used as firewood for household use and charcoal to be traded, regardless of the carrying capacity and recovery, as well as increased activity of search crab seeking mangrove crabs into the region also led to increased damage to mangrove forests.

This work presents an attempt to provide helpful information and integrative condition of mangrove ecosystems in Southern coast of Malang Region. The information contains in the form of the identification of species, mangrove biodiversity of the 18 beaches.

The rest of this paper is organized as follow: Section 2 presents material used and our proposed methods. Section 3 presents obtained results and following by discussion. Section 4 concludes this work.

\section{MATERIAL AND METHODS}

The Southern coast Malang Region is located at $820 \mathrm{~S} 11221 \mathrm{E}$ bordered with Blitar Region to $821 \mathrm{~S} 11257 \mathrm{E}$ bordered with Jember Region. The total area of Malang Region is $3.534,86 \mathrm{~km}^{2}$ with the temperature of rainy season and hot season are $18-23{ }^{\circ} \mathrm{C}$ and 21 $31{ }^{\circ} \mathrm{C}$, respectively. Thus, the minimum rainfall and maximum rainfall are $201 \mathrm{~mm}$ and $400 \mathrm{~mm}$, respectively.

\subsection{THE MALANG COASTAL AREA}

Figure 1 below shows the objects of the coastal Malang Region. The mangrove vegetation are observed at 18 beaches for two years period. 


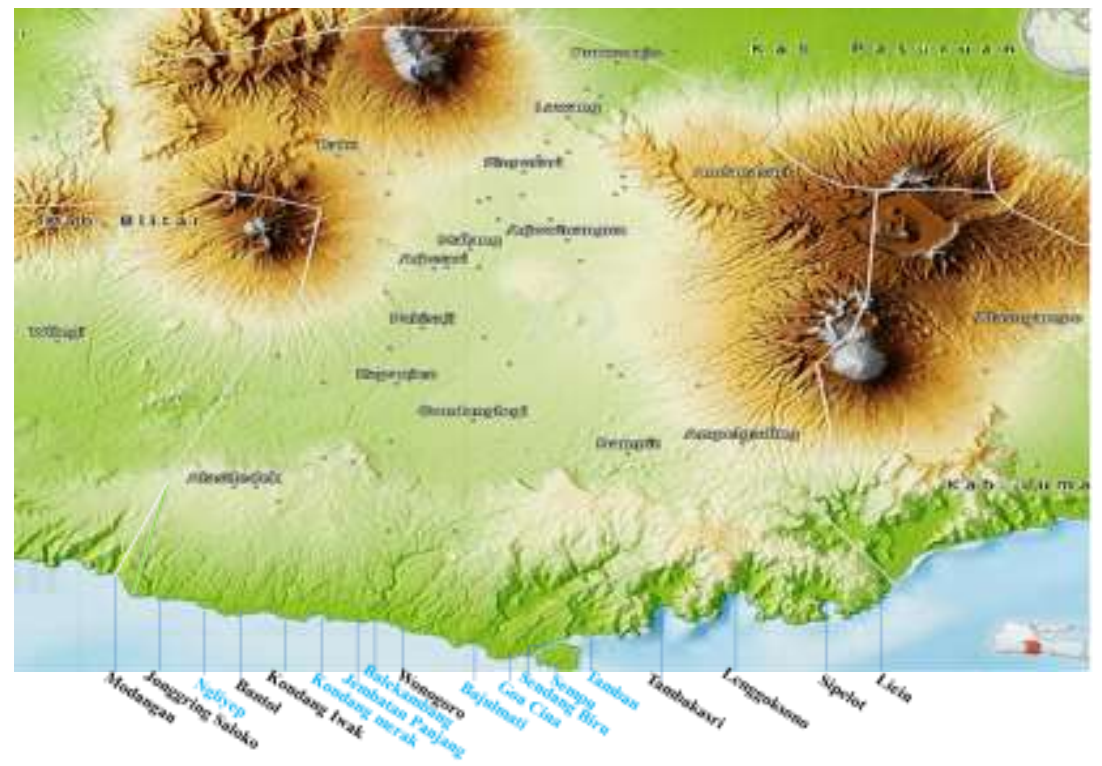

Fig. 1 The Malang Coastal Region

\subsection{PROPOSED METHODS}

In this works, the potential of mangrove forests and mangrove forest management strategies in the coastal of Malang Region are analyzed and mapped. The information contains in the form of the identification of species, mangrove biodiversity of the 18 beaches by two years scheme. The research methods of this study based on data processing of satellite image ALOS (AVNIR-2) and Landsat 7. The software ENVI 4.4 and Arc GIS 9.3 are used for data processing. The identification of various mangrove species using methods of in-situ and laboratory observations. In the first year, the in-situ data are collected. Then in the second year, the in-situ data will be processed the satellite data [7, $8,9]$.

\section{RESULTS AND DISCUSSION}

Figure 2 below shows the satellite image of Malang Coastal Region. Since 2013 the South Route has been developed due to economic strategy management. Consequently, the new objects tourism has been developed while the communities are growing. However, the mangrove vegetation is becoming narrower for hundred hectares.

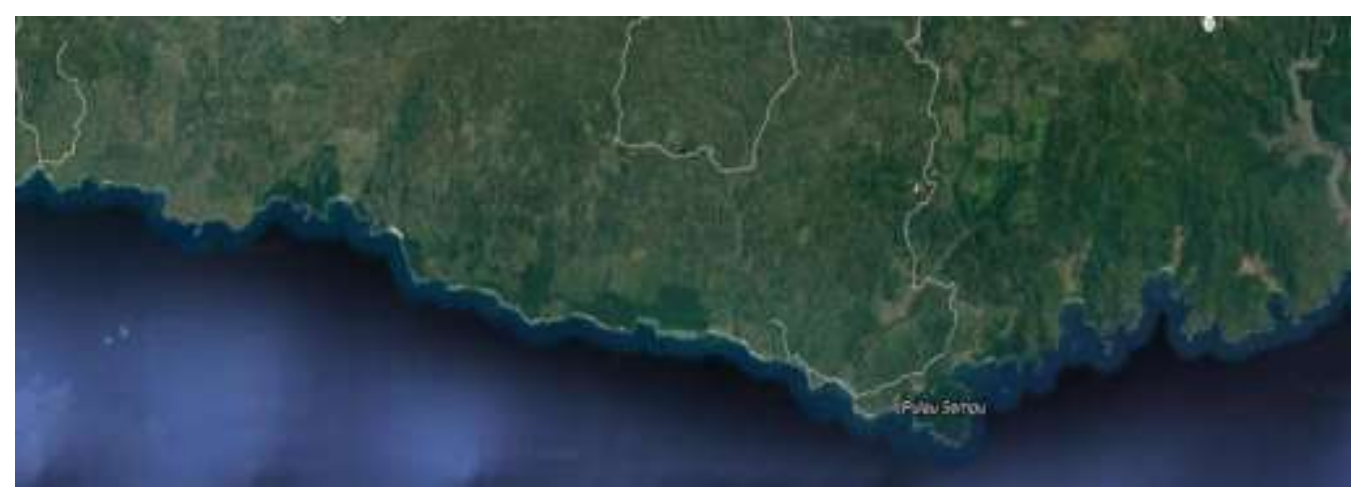

Fig. 2 The satellite image Malang Coastal Region

Figure 3 below shows the satellite image of associated mangrove vegetation domination in Sempu Island and Sendang Biru Area. 


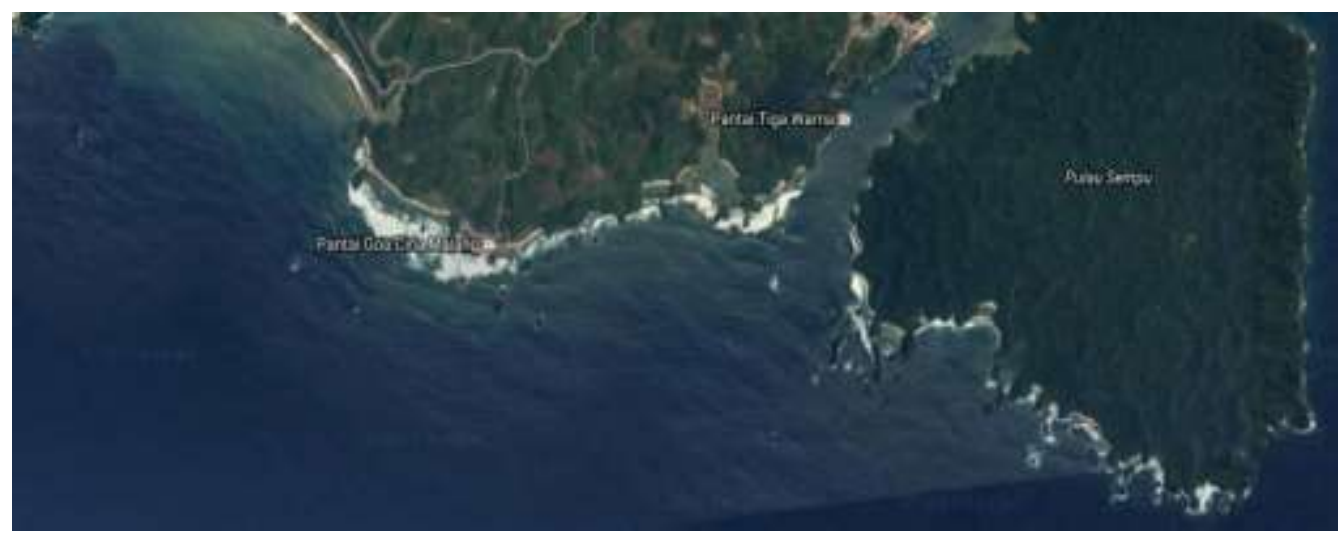

Fig. 3 The satellite image of mangrove distribution at Sempu Island and Sendang Biru

The population of residences have been grown for recent years. However, the development of marine and fisheries sector at this time become one of the development priorities announced by the government Malang. The policy was adopted in view of Malang has 18 beaches with a coastline of $77 \mathrm{~km}$ and is located in the waters of the Indian Ocean is rich in resources large pelagic fish, such as yellow fin tuna (Thunnus albacares), bigeye tuna (Thunnus obesus), Albakora (Thunnus allalunga), southern bluefin tuna (Thunnus macoyii), and gray tuna (Thunnus tonggol) and skipjack (Katsuwonus pelamis). Based on the assessment of fish stocks in the Indian Ocean conducted by the National Commission on stock assessment of Marine fish Resources in 19 981, reported the potential of tuna resources in the South Java, is estimated at 22,000 tons / year with a production rate of 10,000 tons/ year, meaning the new utilization rate reached $45 \%$. Thus, the prospects for development is still wide open, which amounted to 55\%.

Changes in national development paradigm from land-based economic development into ocean-based economic development. Marine development platform used Malang Regency Government's economic development, particularly in South Malang. The Coastal areas of development priority due to the center of fisheries in Malang. The consideration of the coastal areas development need to be planned well, because the coastal area is an area of transition between marine and terrestrial ecosystems with some important insights include: (1) Ecological, areas inland were still influenced by the processes of the marine, such as tide, intrusion sea water, and etc.; (2) Administrative, namely the outer limit upstream from the village beach or definitive arbitrary distance $(2 \mathrm{~km}, 20 \mathrm{~km}$, ff. Of shoreline; and (3) Planning which depends on the problem or the substance that became the focus of the management of coastal areas. Similarly, the processing industry development planning, in order to be sustainable needs to be adjusted with the existing commodity good quantity. Figures 4 and 5 show the examples of mangrove Vegetation Island and mangrove plantation at Sendang Biru, respectively.

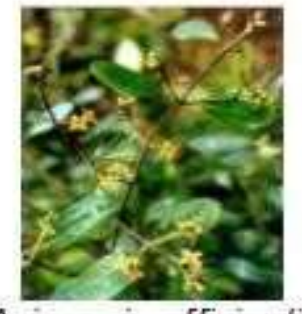

Avicennia officinalis
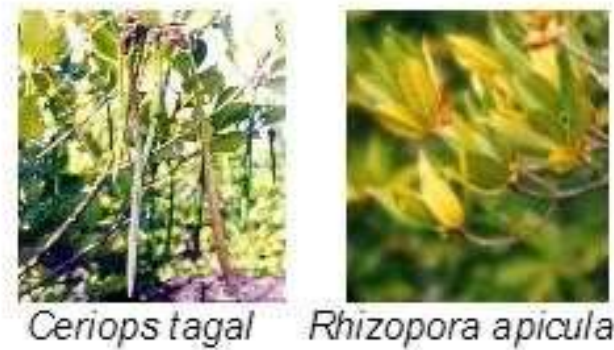

Rhizopora apiculata

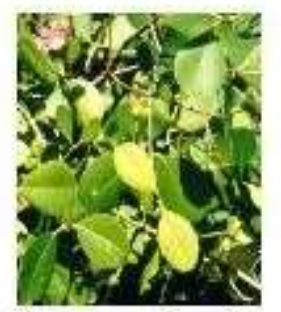

Sonneratia alba

Fig. 4 Mangrove vegetation at Sendang Biru 


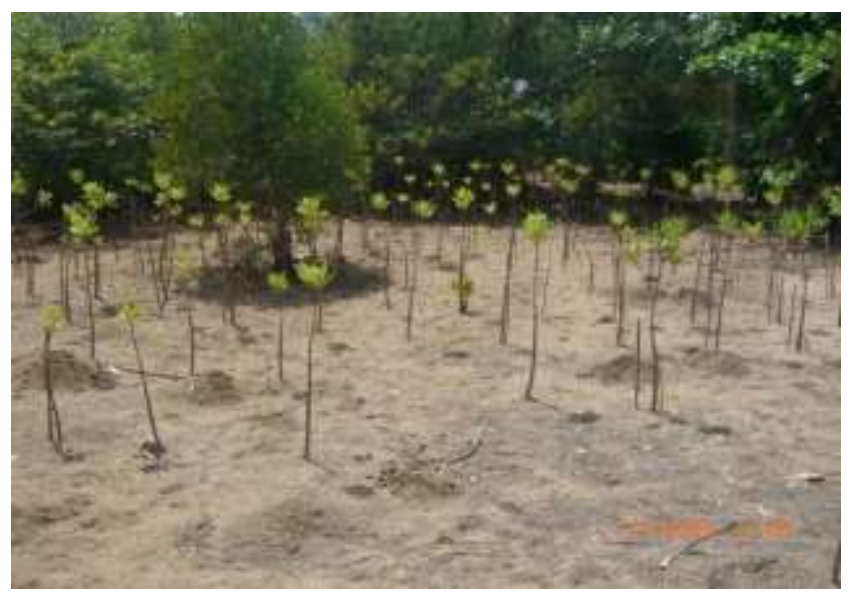

Fig. 5 Mangrove plantation at Sendang Biru

Figure 6 below shows the flowchart of satellite image processing of mangrove vegetation at Tamban Beach (Sendang Biru area). The verified satellite image data of Landsat 7 ETM+ with field work data at Tamban Beach. The mangrove vegetation has been become narrower as $5.4 \mathrm{Ha}$ is shown in Table $\mathrm{I}$.

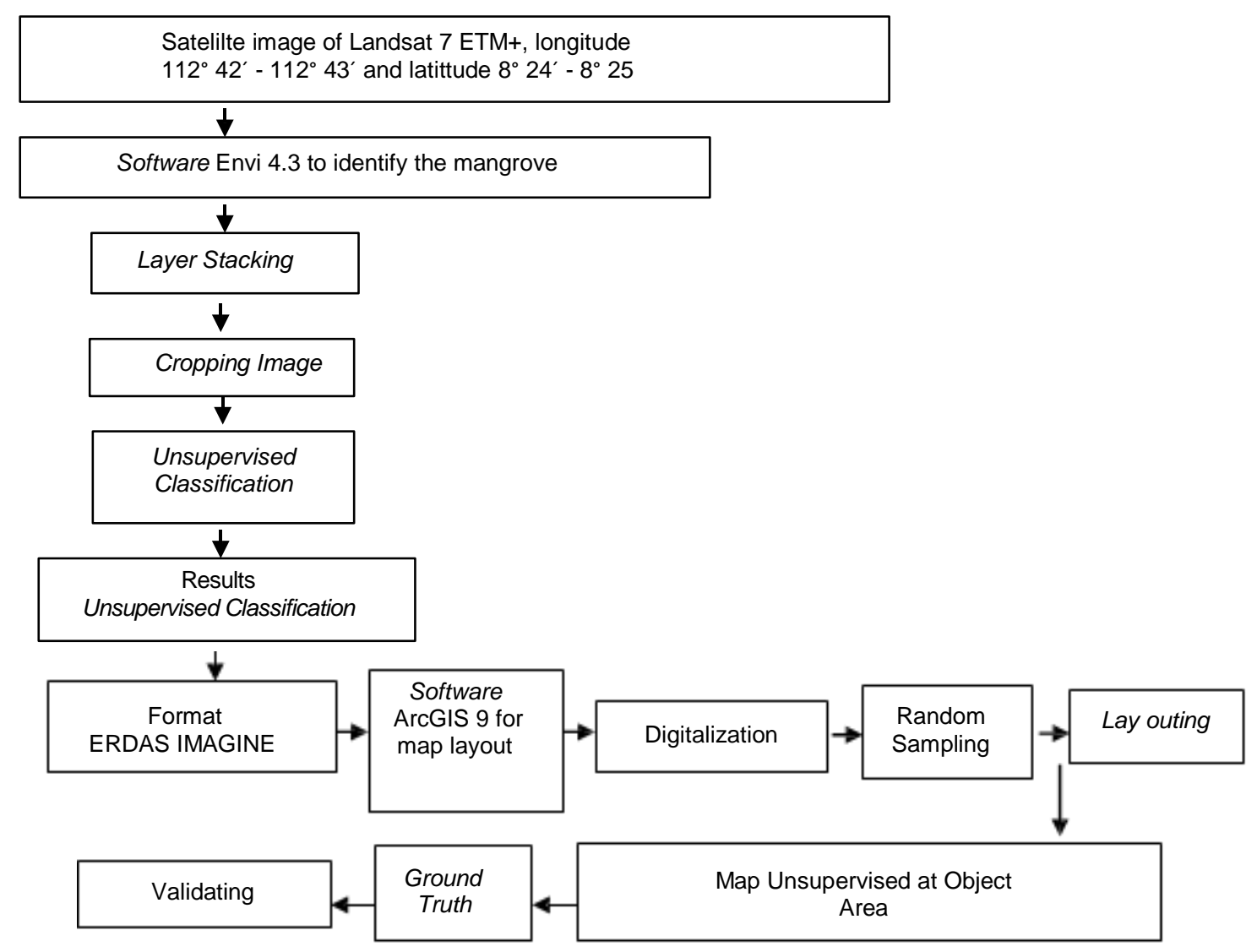

Fig. 6 Flowchart of unsupervised mapping at Tamban Beach (Sendang Biru area) 
Table I. Verified satellite image data of Landsat 7 ETM+ with field work data

\begin{tabular}{lcccccccc}
\hline \multicolumn{1}{c}{ Class } & Mangrove & Forest & Field & $\begin{array}{c}\text { Agriculture } \\
\text { field }\end{array}$ & $\begin{array}{c}\text { Sallow } \\
\text { water }\end{array}$ & Sand & Sea & Total \\
\hline Mangrove & 29 & 0 & 1 & 0 & 0 & 0 & 0 & 30 \\
Forest & 4 & 16 & 0 & 0 & 0 & 0 & 0 & 20 \\
Field & 0 & 1 & 18 & 1 & 0 & 0 & 0 & 20 \\
Agriculture & 0 & 1 & 1 & 16 & 0 & 2 & 0 & 20 \\
field & & & & & & & & \\
Sallow & 12 & 0 & 0 & 0 & 6 & 2 & 0 & 20 \\
Water & 0 & 0 & 0 & 0 & 3 & 17 & 0 & 20 \\
Sand & 0 & 0 & 0 & 0 & 0 & 0 & 20 & 20 \\
Sea & 45 & 21 & 18 & 16 & 9 & 21 & 20 & 150 \\
\hline Total & & & & & & & \\
\hline
\end{tabular}

Figure 7 below shows the map of validated Random Sampling of mangrove vegetation at Tamban Beach (Sendang Biru area).

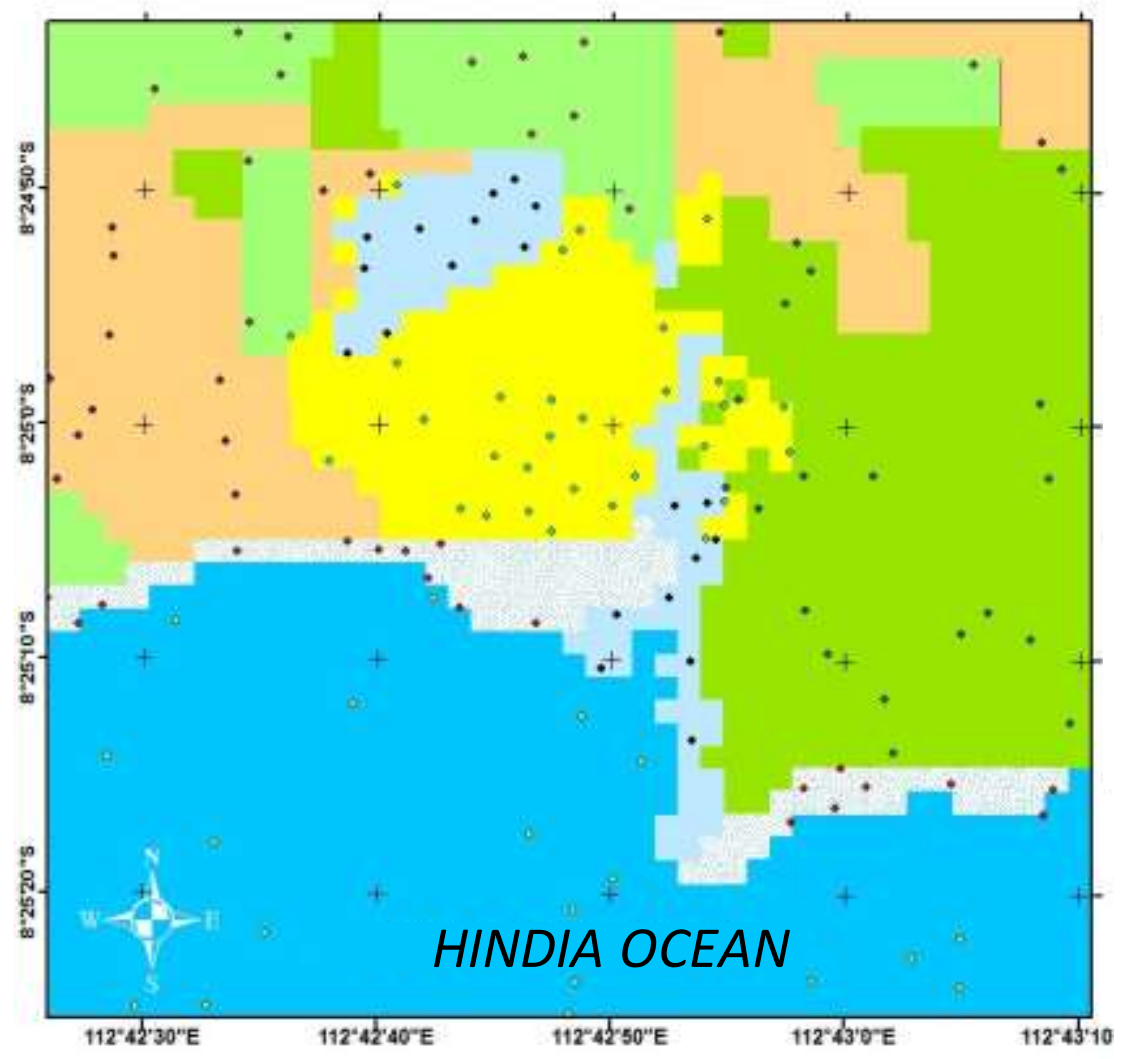

Fig. 7 Map of validated Random Sampling

Table II below shows the mangrove vegetation which identified in Malang Coastal Region. The mangrove vegetation is dominated by associated mangrove. 
Table II. Mangrove Vegetation Diversity in the South Malang

Index of mangrove vegetation and associated salt tolerant plant species identified from the South Malang

No. Scientific name Family

Mangrove Flora

1. Acanthus ebracteatus, ilicifolius, volubilis Acanthaceae

2. Acrostichum aureum, speciosum

3. Aegialitis rotundifolia

Pteridaceae

4. Aegiceras corniculatum

Plumbaginaceae

Myrsinaceae

5. Avicennia alba, marina, officinalis

Avicenniaceae

6. Bruguiera cylindrica, gymnorrhiza, hainessi, parviflora, Rhizophoraceae sexangula

7. Ceriops decandra, tagal

8. Excoecaria agallocha

Rhizophoraceae

9. Heritiera fomes, littoralis

Euphorbiaceae

10. Lumnitzera littorea, racemosa

Sterculiaceae

11. Kandelia kandel

Combretaceae

12. Nypa fruiticans

Rhizophoraceae

13. Rhizophora apiculate, mucronata

Arecaceae

14. Scyphiphora hydrophyllacea

Rhizophoraceae

15. Sesuvium portulacastrum

Rubiaceae

16. Sonneratia alba, apetala, caseolaris, griffithii

Aizoaceae

17. Xylocarpus granatum,moluccensis

Sonneratiaceae

18. Albizia procera

Meliaceae

19. Amyema mackayense

Leguminosae

Loranthaceae

20. Bidens pilosa

Asteraceae

21. Brownlowia tersa

Tiliacea

22. Canavalia maritima

Leguminosae

23. Clerodendum inerme

Verbenaceae

24. Cynodon dactylon

Poaceae

25. Cynometra ramiflora

Leguminosae

26. Dalbergia candenatensis

Leguminosae

27. Dalbergia spinosa

Fabaceae

28. Derris scandens, trifoliata

Leguminosae

29. Dolichandrone spathacea

Bignoniaceae

30. Drymoglossum piloselloides

Polypodiaceae

31. Eclipta alba,

Asteraceae

32. Eupatorium adoratum

Asteraceae

33. Fimbristylis ferruginea

Cyperaceae

34. Finlaysonia abovata

Asclepiadaceae

35. Flagellaria indicata

Flagellariaceae

36. Hibiscus tiliaceus

Malvaceae

37. Hoya carnaso

Asclepiadaceae

38. Ipomoea alba

Convolvulaceae

39. Ipomoeae pes-caprae

Convolvulaceae

40. Leucaena leucocephala

Fabaceae

$\begin{array}{lll}\text { 41. } & \text { Melastoma villosum } & \text { Melastomataceae } \\ \text { 42. } & \text { Merope angulata } & \text { Rutaceae } \\ \text { 43. } & \text { Paspalum sp } & \text { Poaceae } \\ \text { 44. } & \text { Phoenix paludosa } & \text { Arecaceae } \\ \text { 45. } & \text { Pluchea indica } & \text { Asteraceae }\end{array}$




\begin{tabular}{lll} 
46. & Pongamia pinnata & Legununosae \\
47. & Sarcolobus globosus & Asclepiadaceae \\
48. & Scaevola taccada & Goodeniaceae \\
49. & Scirpus $s p$ & Cyperaceae \\
50. & Sesbania $s p$ & Fabaceae \\
51. & Tamarix troupii & Tamaricaceae \\
52. & Vanda sp & Orchidaceae \\
\hline
\end{tabular}

\section{CONCLUSION}

The results have shown that the recent mangrove vegetation (forest) condition in Southern Malang Region is recommended as a prior conservation for sustainability coastal management system. This work also provides the mangrove iBook format and ebook. The hard copy is obliged to the library flora Malang Regency as a supporting information for Southern Malang Region management system and as the academic learning process reference for high school students and universities students after two years' period observation. The strategic management of mangrove forests in Malang Region is people planted by the potential that exists, establish protected forest areas of mangrove that cannot be bothered, further enhancing the role of community-based organizations and empower the community, dissemination to the public about the dangers of harvesting of mangroves, a touch of technology in the development of mangrove, the people involved in every decision-making on mangroves and increasing the role of government, elucidation of environmental and mangrove ecosystems, provide insight to the public about the use of mangrove, improving education/ training to the community, as well as consultation between the public and the government about the use and management of mangrove, socialization the application of government regulations on the environment, involving the community in the preparation of the planning and implementation of mangrove management, government and the community together to support the management of mangrove, the increase in planting mangroves around the coast. In principle, the position of mangrove forest management model in Malang Region in the category of growth and stability strategy is a strategy that is implemented without changing the direction of a predetermined strategy.

\section{ACKNOWLEDGEMENT}

The Authors would like to thank to Ministry of Research, Technology and Higher Education of Republic of Indonesia for providing the funding decentralization scheme research program. Also, The State Polytechnic of Malang that supporting to attend this conference. The help of Indrazno Sirahjuddin for supporting the scientific writing is also appreciated.

\section{REFERENCES}

[1] Onrizal, A. Purwoko, and M. Mansor. 2009. Impact of mangrove forests degradation on fisherman income and fish catch diversity in eastern coastal of North Sumatra, Indonesia. International Conference on Natural and Environmental Sciences 2009 (ICONES'09) at the Hermes Palace Hotel Banda Aceh on May 6-8, 2009.

[2] Tarigan, M. S. 2008. Sebaran dan Luas Hutan Mangrove di Wilayah Pesisir Teluk Pising Utara Pulau Kabaena Provinsi Sulawesi Tenggara. Bidang Dinamika Laut, Pusat Penelitian Oseanografi, LIPI, Jakarta 14430, Indonesia. Makara, Sains, 12(2), November 2008: 108-112.

[3] Hogarth, P.J. 1999. The Biology of Mangroves. Oxford University Press, Oxford.

[4] Walters, B.B., P. Ronnback, J.M. Kovacs, B. Crona, S.A. Hussain, R. Badola, J.H. Valiela, I., J. L. Bowen, dan J. K. York. 2001. Mangrove Forest: One of the World's Threatened Major Tropical Environments. Bioscience 51(10), 807-815. 
[5] Primavera, E. Barbier, dan F. Dahdouh-Guebas. 2008. Ethnobiology, Socio-Economic and Management of Mangrove Forests: a review. Aquatic Botany 89: 220-236

[6] Dave, R. 2006. Mangrove ecosystem of south, west Madagascar: an ecological, human impact, and subsistence value assessment. Tropical Resources Bulletin 25: 7-13

[7] Landsat Imagery. 2016. An Overview the Global Land Cover Facility (GLCF). University of Maryland http://www.glcf.umd.edu/data/landsat/. Accessed on 10 November 2017.

[8] Jensen, J.R. 1998. Introductory Digital Image Processing a Remote Sensing Perspective. Prentice Hall. New Jersey. 361p. 2010.

[9] Santosa, P.B. 2005. Pemetaan Awal Hutan Mangrove Pantai Cairns Berdasarkan Data Landsat TM (Preliminary Mapping of Mangrove Forest of the Cairns Coast Based On Landsat TM). Pertemuan Ilmiah Tahunan MAPIN XIV "Pemanfaatan Efektif Penginderaan Jauh untuk Peningkatan Kesejahteraan Bangsa" pada tanggal 14-15 September 2005. Jurusan Teknik Geodesi UGM. Yogyakarta. 
International Journal of Advanced Science and Technology Vol.130 (2019) 